\title{
Bilecik'te Tüketime Sunulan Ayva Lokumlarının Mikrobiyolojik ve Kimyasal Kalitesinin Araştırılması
}

\section{Investigation of Microbiological and Chemical Quality of Quince Delights Offered for Consumption in Bilecik}

\begin{abstract}
Alper Kürşat Demirkayaa ${ }^{1}$ Nurşah Gülöksüz Şahin² ${ }^{2 *}$
Geliş / Received: 11/05/2021

Revize / Revised: 04/06/2021

Kabul / Accepted: 05/06/2021

ÖZ

$\mathrm{Bu}$ araştırmada, Bilecik ilinde satışa sunulan geleneksel 20 adet ayva lokumu numunelerinin mikrobiyolojik özelliklerinden toplam aerobik mezofilik bakteri, Enterobacteriaceae, maya ve küf, koliform grubu, Salmonella ile Staphylococcus aureus sayısı ve kimyasal özelliklerinden rutubet (\%), toplam kül (\%), toplam şeker (\%) ve pH değerleri belirlenmiş̧tir. Elde edilen bulgularda, referans olarak Türk Standartları TS 8444 Lokum Standardı kullanılmış ve lokumlar bu yönden değerlendirilerek hijyenik kaliteleri ortaya koyulmaya çalışılmıştır. Lokum numunelerinin toplam aerobik mezofilik bakteri ile maya ve küf sayıları sirasıyla 1.00-7.95 log kob/g, <1.00-6.60 $\log \mathrm{kob} / \mathrm{g}$ arasında, rutubet (\%), toplam kül (\%), toplam şeker (\%) ve $\mathrm{pH}$ oranları sirasıyla \%6.88 - 18.59, \%0.090.42, \%82.06-88.40, 5.21-7.85 aralığında bulunmuştur. Örneklerin hiçbirinde Staphylococcus aureus tespit edilmemiştir. Elde edilen bulgulara göre; 3 (\%15.00) lokum örneği toplam aerobik mezofilik bakteri, Enterobacteriaceae, koliform grubu bakteri ve Salmonella sayıları yönünden, $5(\% 25.00)$ lokum örneğinin rutubet miktarı (\%) ve toplam şeker miktarı (\%) yönünden Türk Standartları (TS 8444) lokum standardına göre uygun olmadığı tespit edilmiştir. Bu çalışmada tespit edilen verilere göre lokum örneklerinin genellikle beklenen hijyenik kalite kriterlerine uygun olmadığı bulunmuştur.
\end{abstract}

Anahtar Kelimeler- Hijyen, Lokum, Mikrobiyolojik Kalite

\begin{abstract}
In this study, the microbiological properties of 20 traditional quince delight samples offered for sale in Bilecik province include total aerobic mesophilic bacteria, Enterobacteriaceae, yeast and mold, coliform group, Salmonella and Staphylococcus aureus number and chemical properties moisture (\%), total ash (\%), total sugar (\%) and $\mathrm{pH}$ values were determined. In the findings obtained, Turkish Standards TS 8444 Turkish Delight Standard was used as a reference and it was tried to reveal the hygienic quality of delight by evaluating them in this respect. Total aerobic mesophilic bacteria, yeast and mold, numbers between 1.00-7.95 log cfu/g, <1.00-6.60 log cfu / g, humidity (\%), total ash (\%), total sugar (\%) and pH ratios of Turkish delight samples, respectively. 6.88-18.59\%, $0.09-0.42 \%, 82.06-88.40 \%, 5.21-7.85$, respectively. Staphylococcus aureus was not detected in any of the samples. According to the findings obtained; 3 (15.00\%) Turkish delight samples were complied with Turkish Standards (TS 8444) Turkish Standards (TS 8444) in terms of total aerobic mesophilic bacteria, Enterobacteriaceae, coliform group bacteria and Salmonella counts, moisture content (\%) and total sugar content (\%) of $5(25.00 \%)$ delight
\end{abstract}

1İletişim: alperkursat.demirkaya@bilecik.edu.tr .(https://orcid.org/0000-0002-7994-7832)

Gıda İşleme Bölümü, Bilecik Şeyh Edebali Üniversitesi, Meslek Yüksek Okulu, Bilecik, Türkiye

${ }^{2 *}$ Sorumlu yazar iletișim: nursahguloksuz@gmail.com (ORCID ID: 0000-0003-0511-4472)

Biyoteknoloji Anabilim Dalı, Lisansüstü Eğitim Enstitüsü, Yüksek Lisans, Bilecik, Türkiye 
samples. It has been determined that it is not suitable. According to the data determined in this study, it was found that the delight samples generally did not meet the expected hygienic quality criteria.

\section{Keywords- Hygiene, Microbiological Quality, Turkish Delight}

\section{GİRIS}

Lokum, Türk standartları Enstitüsü TS 8844 Lokum standardına göre "şeker, nişasta, su, katkı maddeleri ile hazırlanan lokum kütlesine gerektiğinde çeşni maddeleri, kuru ve/veya kurutulmuş meyveler vb. maddelerin ilavesiyle tekniğine uygun olarak hazırlanan bir mamuldür" diye tanımlanmıştır [1] Dünyanın en eski tatlıları arasında yer alan lokum, temelde şeker ve nişasta hammaddesinden oluşan, kökeni Selçuklulara dayanan, 15. y.y.'dan beri Anadolu'da ve Osmanlı topraklarında bilinen, Osmanlıca boğaz rahatlatan anlamına gelen rahat-ul hulküm olarak adlandırılan uluslararası üne sahip bir Türk tatlısıdır. 18. yüzyılda bir İngiliz turist tarafından Avrupa'ya taşınmıştır ve burada Türk tatlısı veya Türk zevki anlamına gelen "Turkish delight" adıyla tanınmıştır. İlerleyen zamanlarda Balkanlar ve Fransa'da "Lokhum" adıyla uluslararası şekercilik literatüründe yer almıştır [26]. Türk Gida Kodeksi Lokum Tebliği'ne göre de lokum “ şeker, nişasta, içme suyu ve sitrik asit veya tartarik asit veya potasyum bitartarat ile hazırlanan lokum kitlesine gerektiğinde çeşitli çeşni maddeleri, kuru ve/veya kurutulmuş meyveler ve benzeri maddelerin ilavesiyle tekniğine uygun olarak hazırlanmış üründür." diye tanımlanmıştır [7]. Lokum üretiminde Türk Gıda Kodeksi Gıda Katkı Maddeleri Yönetmeliği'ne uygun renklendirici ve tatlandırıcılar kullanılmakta ve ceviz, fıstık, fındık, Hindistan cevizi gibi çeşni maddeleride ilave edilebilmektedir [8]. Lokum, ülkemiz dışında Yunanistan, Bosna Hersek, Romanya, Ermenistan ve Arnavutluk'ta da üretilmektedir [3, 4, 9]. Lokum imalatı ülkemizin her ilinde küçük işletmelerce yapılmasına rağmen artan tüketim ve ihracat nedeniyle büyük şekerleme fabrikalarında da üretilmektedir [10]. Lokum üretiminde, üretim aşamalarının son ürün kalitesi üzerinde önemli etkileri bulunmaktadır. Üretilen lokumun istenen kalitede tüketiciye sunulmasında ise paketleme ve depolamanın öneminin büyük olduğu belirtilmiştir. Özellikle uygulanan yanlış depolama koşulları mikrobiyal yükün artmasına neden olabilmektedir [4]. Batu ve Kırmacı [9], lokum üretiminde potansiyel problemlerin; bileşen kusurları, pişirme sırasındaki enerji kayıpları, alet ve ekipmanların hijyen ve paslanma sorunları, personel hijyeni, paketleme ve depolama sorunları olduğunu belirtmişlerdir. Batu ve Kırmacı [9], Zorba ve İpek [11] ile Gök ve Batu [12] yapmış oldukları çalışmalarda lokum üretim hattında HACCP uygulanması gerektiğini belirtmişlerdir. Gıda güvenliğinin öneminin arttığı günümüzde, bölgede en çok tanınan ve tüketilen tatlılardan biri olan lokumun mikrobiyal risk profili henüz mevcut değildir. Aynı zamanda, lokum üretimi yapan işletmelerin farklı hammaddeleri kullanarak lokum üretimi yapmasının yanında aynı işletmede bile hammaddelerin değişik karışım oranlarında kullanılarak standart bir ürün üretiminin sürekli olarak sağlanamaması, lokumların kimyasal bileşiminde farklılığa neden olmaktadır. Genellikle ufak çaplı bir sanayi dalı olarak çalışan işletmelerde üretilen lokumda, standart ürün üretiminin sürekliliğini sağlamak oldukça zordur. Bunlara ek olarak uygun olmayan şartlarda muhafaza edilen ürünlerdeki üretim hataları lokumlarda kusurlara neden olabilir. Bu sebeplerden ötürü her zaman standart ve aynı kalitede lokum üretimi yapılamamaktadır. Bu çalışma, Bilecik ilinde tarımsal üretimde önemli yeri olan ve özellikle Bilecik ili Osmaneli ilçesinde üretimi yoğun olan ayvadan üretilen tüketici tarafından tercih edilen ayva lokumunun kimyasal ve mikrobiyolojik kalite kriterlerinin belirlenerek, tüketici sağlığını korumak için alınması gereken önlemlerin tespit edilmesi ve uygulanması, ürünün kalitesini geliştirmeye yönelik çalışmaların yapılması için bir temel oluşturabilmek için gerçekleştirilmiştir.

\section{MATERYAL VE YÖNTEM}

\section{A. Materyal}

Bilecik ilinde faaliyet gösteren satış yerlerinde (şekerli ürün satışı işletmeleri, market ve fabrika satış mağazası) 200 g'lık ambalajlarda tüketime sunulan ambalajlı toplam 20 adet ayva lokum örneği, rutin satış prosedürüne ve ambalaj materyaline müdahale edilmeden rastgele örnekleme metoduna göre temin edilerek soğuk zincir kurallarına uyularak laboratuvara getirilmiş ve analizler tamamlanıncaya kadar buzdolabı şartları altında $\left(4^{\circ} \mathrm{C}\right)$ muhafaza edilmiştir.

\section{B. Metot}

Lokum örneklerinin toplam mezofilik aerobik bakteri (TMAB) sayımında Plate Count Agar (PCA, Merck) kullanıldı. $37 \pm 1{ }^{\circ} \mathrm{C}$ 'de 3 gün inkübe edildikten sonra oluşan koloniler değerlendirildi. Koliform grubu bakteri sayımında Violet Red Bile Agar (VRBA, Merck) kullanıldı ve $35 \pm 1{ }^{\circ} \mathrm{C}$ 'de 2 gün inkübe edildikten sonra oluşan koloniler değerlendirildi. Enterobacteriaceae sayımında Violet Red Bile Dekstroz Agar (VRBD, Merck) kullanıldı 
ve $35 \pm 1{ }^{\circ} \mathrm{C}$ 'de 2 gün inkübe edildikten sonra oluşan koloniler değerlendirildi. Staphylococcus aureus sayımında Baird Parker Agar (BPA, Merck) kullanıldı ve $37 \pm 1{ }^{\circ} \mathrm{C}$ 'de 2 gün inkübe edildikten sonra oluşan koloniler sayıldı. Salmonella spp. sayımında Brilliant Green Phenol Red Agar (Merck) kullanıldı. $37 \pm 1{ }^{\circ} \mathrm{C}^{\prime}$ de 1 gün inkübe edildikten sonra oluşan koloniler sayıldı [13]. Maya ve küf sayımında ise Rose Bengal Chloramphenicol Agar (RBC, Merck) kullanıldı. $22 \pm 1^{\circ} \mathrm{C}$ 'de 5 gün inkübe edildikten sonra oluşan koloniler değerlendirildi [14]. Lokum numunelerinin rutubet (\%), toplam kül (\%), toplam şeker $(\%)$ ve $\mathrm{pH}$ analizleri, Lokum Standardı'nda önerilen metoda göre belirlendi [2].

\section{BULGULAR VE TARTIŞMA}

Yapılan çalışma neticesinde, incelenen toplam 20 adet lokum numunesinin; kimyasal özelliklerinin ortalama değerleri Tablo 1'de, mikrobiyolojik özelliklerinin ortalama değerleri (log kob/g) Tablo 2'de ve yüzde dağılımı ile frekans sayıları Şekil 1'de verilmiştir. Yapılan çalışmada, lokum numunelerinin rutubet (\%), toplam kül (\%), toplam şeker (\%) ve pH oranları sirasıyla \%6.88-18.59, \%0.09-0.42, \%82.06-88.40, 5.21-7.85 aralığında tespit edilmiştir. Türk Standartları Enstitüsü TS 8444 Lokum Standardına göre küp veya dikdörtgen prizma şeklinde meyveli lokumda olması gereken toplam rutubet miktarı en çok \%15, toplam şeker (invert şeker olarak) miktarı en az \%85 olması gerektiği belirtilmiştir [2]. Tespit edilen bulgular sonucunda, Türk Standartları Enstitüsü TS 8444 Lokum Standardı'na göre lokum numunelerinden 5 (\%25.00) lokum örneğinin rutubet miktarı (\%) ve toplam şeker miktarı (\%) yönünden uygun olmadığı tespit edilmiştir [2]. Tespit edilen veriler örneklerin tümünde farklı oranda olduğu bulunmuştur. Yapılan araştırmalarda, bazı faktörlere bağlı olarak lokumların kimyasal bileşenleri arasında farklılık gösterdiği belirtilmiştir $[4,15,16,17,18]$. Farklı araştırmacıların verileri ve çalışmada elde edilen sonuçların farklı olması, lokum üretiminde farklı hammadde ve/veya üretim yöntemlerindeki farklılıklardan ve depolama koşullarından kaynaklandığı öngörülebilir. Toplam aerobik mezofilik bakteri, Enterobacteriaceae, maya ve küf, koliform grubu bakteri, Salmonella ve Staphylococcus aureus sayıları Tablo 2 'de verilmiştir. İncelenen lokum numunelerinde toplam aerobik mezofilik bakteri sayısı 1.00-7.95 log kob/g arasında, numunelerin toplam aerobik mezofilik bakteri sayıs1 ortalaması ise $2.96 \pm 1.65 \mathrm{log} \mathrm{kob} / \mathrm{g}$ 'dır. Maya ve küf sayıları <1.00-6.60 log kob/g değerleri arasında ve numunelerin maya ve küf sayısı ortalama değeri ise $1.06 \pm 1.89 \mathrm{log} \mathrm{kob} / \mathrm{g}$ 'dır. Koliform grubu bakteri sayıs1 $<1.00-2.11 \mathrm{log} \mathrm{kob} / \mathrm{g}$ arasındadır, örneklerin koliform grubu bakteri say1s1 ortalamas1 $0.26 \pm 0.67 \mathrm{log} \mathrm{kob} / \mathrm{g}$ 'dır. Enterobacteriaceae say1s1 $<1.00-5.00 \mathrm{log} \mathrm{kob} / \mathrm{g}$ arasındadır, örneklerin Enterobacteriaceae sayısı ortalaması $0.38 \pm 1.16$ log kob/g'dır. Salmonella sayıs $<1.00$ $2.81 \mathrm{log} \mathrm{kob} / \mathrm{g}$ arasındadır, örneklerin Salmonella sayısı ortalaması $0.32 \pm 0.74 \mathrm{log} \mathrm{kob} / \mathrm{g}$ 'dır. Numunelerde, koliform grubu bakteri, Enterobacteriaceae, Salmonella'ya 20 adet lokum örneğinde, 17 (\%85.00) numunede hiç rastlanılmazken, 3 (\%15.00) örnekte sirasıyla; en az $1.00 \mathrm{log}$ kob/g ve en fazla $2.11 \mathrm{log}$ kob/g; en az $1.00 \mathrm{log}$ kob/g ve en fazla $5.00 \mathrm{log} \mathrm{kob} / \mathrm{g}$; en az $1.30 \mathrm{log} \mathrm{kob} / \mathrm{g}$ ve en fazla $2.81 \mathrm{log} \mathrm{kob} / \mathrm{g}$ olarak bulunmuştur. Numunelerin hiçbirinde Staphylococcus aureus tespit edilmemiştir. Türk Standartları Lokum Standardı'na göre lokumlarda bulunabilecek toplam aerobik mezofilik bakteri sayısı en çok $5.00 \mathrm{kob} / \mathrm{g}$, fekal koliform ve Salmonella spp. bulunmamalıdır [2]. İncelenen açık 20 adet lokum örneğinden, 3 (\%15.00) örnek toplam aerobik mezofilik bakteri, Enterobacteriaceae, koliform grubu bakteri ve Salmonella sayıları yönünden Türk Standartları lokum standardına göre uygun olmadığı belirlenmiştir [2]. Bu sonuçlara göre hijyen ve sanitasyon kurallarına uyulmadığı anlaşılmaktadır. Çalışmamızda elde edilen bulgular, İpek [18], Doyuran ve ark. [4], Sırıken ve Çadırcı [19], Özyaral ve ark. [20] ve Molla [21]'nın yapmış oldukları çalışmalar ile benzerlik göstermektedir.

Tablo 1. Lokum numunelerinin kimyasal analiz sonuçları

\begin{tabular}{ccccc}
\hline Özellik & N & En Küçük & En Büyük & Ortalama \\
\hline Rutubet (\%) & 20 & 6.88 & 18.59 & $12.81 \pm 2.68$ \\
Toplam Kül (\%) & 20 & 0.09 & 0.42 & $0.22 \pm 0.10$ \\
Toplam Şeker (\%) & 20 & 82.06 & 88.40 & $85.94 \pm 1.58$ \\
pH & 20 & 5.21 & 7.85 & $7.13 \pm 0.60$ \\
\hline
\end{tabular}




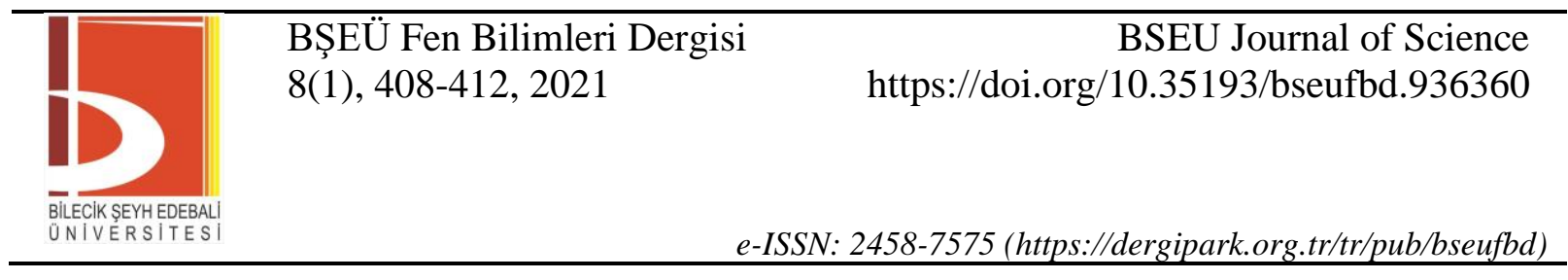

Tablo 2. Lokum numunelerinin mikrobiyolojik analiz sonuçları

\begin{tabular}{lllll}
\hline Özellik & $\mathbf{N}$ & En Küçük & En Büyük & Ortalama \\
\hline TMAB* & 20 & 1.00 & 7.95 & $2.96 \pm 1.65$ \\
Koliform grubu bakteri & 20 & $<1.00$ & 2.11 & $0.26 \pm 0.67$ \\
Maya ve Küf & 20 & $<1.00$ & 6.60 & $1.06 \pm 1.89$ \\
Enterobacteriaceae & 20 & $<1.00$ & 5.00 & $0.38 \pm 1.16$ \\
Salmonella spp. & 20 & $<1.00$ & 2.81 & $0.32 \pm 0.74$ \\
Staphylococcus aureus & 20 & & $<1.00$ & \\
\hline
\end{tabular}

*TMAB: Toplam Aerobik Mezofilik Bakteri

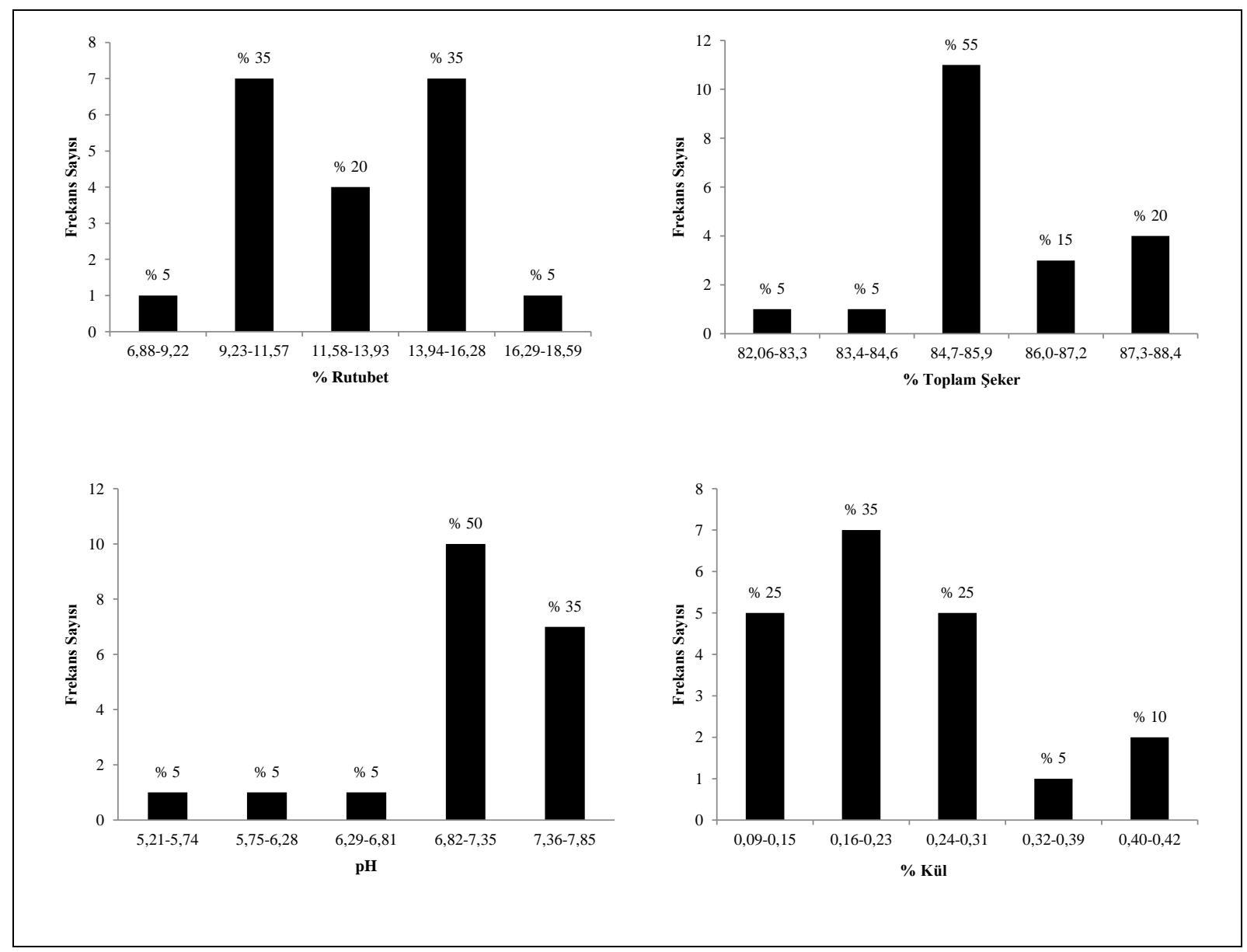

Şekil 1. Lokum numunelerinin yüzde dağılımı ile frekans sayıları

\section{SONUÇ}

Sonuç olarak; Bilecik ilinde tüketilen lokumların, üretiminde kaliteli hammadde kullanılmaması, üretim esnasında kullanılan her türlü alet, ekipman, ortam ve personel hijyeninin eksik olması, hijyenik olmayan ambalaj materyallerinin kullanılması veya hijyenik olmayan metotlarla yapılıyor olması ve üretim tekniklerindeki farklılıklar nedeniyle mikrobiyal yükünün, belirlenen sınır değerlerinin üzerinde saptanmasında ve kimyasal özelliklerin farklı olmasında etkendir. Ürünün raf ömrünün uzatılması ve halk sağlığı açısından, üretimde hijyen kurallarına uyulması ve üretim metotlarında standardizasyon sağlanmalıdır. Bu koşullar ise üretimde gelişmiş teknolojilerin kullanımı ve bilinçli uygulamaların sürekliliği ile mümkün olabileceği öngörülmektedir. 


\section{KAYNAKLAR}

[1] Altan, A. (2001). Özel Gıdalar Teknolojisi. Çukurova Üniversitesi Ziraat Fakültesi. Yayınları, No,178, Adana.

[2] TSE, (1990). Türk Standartları Enstitüsü, TS 8444 Lokum Standardı, Ankara.

[3] Batu, A. (2006). Türk lokumu üretimi tekniği ve kalitesi. Glda Teknolojileri Elektronik Dergisi, 1, 35-46.

[4] Doyuran, S. D., Gültekin, M. \& Güven, S. (2004). Geleneksel gidalardan lokum üretimi ve özellikleri. Geleneksel Gidalar Sempozyumu. 23-24 Eylül, Van. 334-342.

[5] Kavak, D. D. \& Akpunar, E. B. (2018). Quality characteristics of Turkish delight (lokum) as influenced by different concentrations of cornelian cherry pulp. J. of Food Processing and Preservation, 42(7), e13656.

[6] Kaya, S. \& Tattan, G. Ö. (2017). Thermal and Textural Changes of Turkish Delight with Storage Relative Humidity. J. of Food Science and Engineering, 7, 186-191.

[7] TGK, (2020). Türk Glda Kodeksi, Lokum Tebliği, Resmi Gazete. 12.09.2013- 28763, Ankara.

[8] TGK, (2013). Türk Gıda Kodeksi, Gida Katk Maddeleri Yönetmeliği, Resmi Gazete. 30.05.2013- 28693, Ankara.

[9] Batu, A. \& Kırmac1, B. (2006). Lokum üretimi ve sorunları. Gida Teknolojileri Elektronik Dergisi, 3, 37-49.

[10] Akpunar, E. (2015). Türk lokumu üretiminde kızılcık (ergen) meyvesinin doğal renklendirici olarak kullanılması ve depolama stabilitesinin araştırılması. Yüksek Lisans Tezi, Afyon Kocatepe Üniversitesi, Fen Bilimleri Enstitüsü, Afyonkarahisar.

[11] Zorba, M. \& İpek, D. (2007). Gıda endüstrisinde risk analizi ve yönetimi. Akademik Gıda Dergisi, 5(28), 2835.

[12] Gök, V. \& Batu, A. (2008). HACCP Sisteminin Lokum Üretiminde Uygulanması. Gıda Teknolojileri Elektronik Dergisi, 1, 19-25.

[13] Harrigan, W. F. (1998). Laboratory Methods in Food Microbiology, Third Edition. Academic Pres. London. $217-219$

[14] Jarwis, B. (1998). Comprasion of an improved rose-bengal chlortetracyline agar with other media fort the selective isolation and enumeration of moulds and yeasts in food. Journal of Applied Bacteriology, 36, 723727

[15] Altuğ, T. \& Gönül, M. (1987). Lokumda şeker, kurumadde ve nem tayin metotları üzerine bir çalışma. Ege Üniversitesi Mühendislik Fakültesi Dergisi, 1(1), 167.

[16] Kaftan, A. (2002). Kalorisi düşürülmüş lokum üretiminde bazı katkı maddelerinin kullanılabilirliğinin araştırılması. Yüksek Lisans Tezi, Ege Üniversitesi, Fen Bilimleri Enstitüsü, İzmir.

[17] Çetin, G. (2003). Bazı lokum çeşitlerinin kalite özelliklerindeki değişimlerin araştırılması. Yüksek Lisans Tezi, Ege Üniversitesi Fen Bilimleri Enstitüsü, İzmir.

[18] İpek, D. (2009). Üretim aşamaları ve farklı ambalajlama tekniklerinin lokum kalitesine etkisi. Yüksek Lisans Tezi, Çanakkale Onsekiz Mart Üniversitesi, Fen Bilimleri Enstitüsü, Çanakkale.

[19] Sırıken, B. \& Çadırcı, Ö. (2006). Köfte (Pişmemiş), Yas Pasta ve Lokumun Mikrobiyolojik Analizleri. 2. Ulusal Veteriner Gıda Hijyeni Kongresi. 18-20 Eylül, İstanbul. 209-310.

[20] Özyaral, O., Keskin, Y., Baskaya, R., Lüleci, E. \& Gülen, D. (2007). Şeker ve şeker katkılı besin maddelerinde kserofilik-kserotoleran küfler. Türk Mikrobiyoloji Cemiyeti Dergisi, 37(1), 43-50.

[21] Molla, E. M. (2011). Glikoz şurubu ve sakkarozun hammadde olarak kullanılması ile üretilen sade ve sultan lokumlarında kalite bileşenlerinin belirlenmesi ve raf ömrüne etkisi. Yüksek Lisans Tezi, Afyonkarahisar Kocatepe Üniversitesi, Fen Bilimleri Enstitüsü, Afyonkarahisar. 